\title{
COMMUNITY'S SYNCRETISM ON SUNAN KUDUS TEACHING
}

\author{
Rizal Akbar Aldyan \\ rizalakbar@student.uns.ac.id \\ Universitas Sebelas Maret, Surakarta \\ J1. Ir. Sutami No. 36A, Surakarta, Indonesia
}

\begin{abstract}
:
Sunan Kudus or Syayid Ja'far Shadiq is one of Walisongo (Nine Saints) distributing Islam religion in Indonesia, particularly in Kudus area. Sunan Kudus proselytized Islam religion in $15^{\text {th }}$ century. The proselytizing strategies taken by Sunan Kudus were, among others: embracing Hindu community in which many people holding on Hindu and Buddha religions at that time. To invite Hindu and Buddha people to enter Islam, Sunan Kudus used cow as his approach, Sunan Kudus loved cow just like Hindu adherents' belief that did not slaughter it, and even Sunan Kudus exemplified the importance of cow in Al-Quran, because one of Surrah in Al-Quran is Surrah Al Baqarah (female cow). Until today, Kudus people still believe (syncretize) of not slaughtering cow. Dandangan tradition was conducted by Sunan Kudus in the past to welcome Ramadhan month by sending pray to the dead ancestors. This Dandangan activity is still trusted by Kudus people even it develops into religious tourist destination. Sunan Kudus in his proselytization taught his santris (pupils) to understand and to apply Gusjigang (bagus, ngaji, and dagang [English: good, ngaji (studying Al-Quran), and trading) philosophy. This Gusjigang philosophy is still implemented by Kudus people until today. Selametan tradition with Asyura porridge was the one conducted by Sunan Kudus constituting Prophet Nuh's sedekah (alms) when he was safe from great flood on 10 Muharram.
\end{abstract}

Keywords: Islamization, Syncretism, Sunan Kudus, Community tradition.

\section{Introduction}

Sunan Kudus is the son of Sunan Undung. Sunan Undung himself is the son of the brother of Sultan of Egypt, the younger brother of Rara Dampul. Sunan Undung and his sister, Rara Dampul, went to the land of Puser Bumi in Cirebon and met Syarif Hidayat, their cousin who became Sunan in Gunung Jati. Syarif Hidayat suggested that Undung went to Ampeldenta to study with Sunan Ampel. Undung went to Ampeldenta and became the beloved disciple of Sunan Ampel. Undung was later married to Sunan Ampel's grandson named Syarifah, known as Nyi Ageng Manila, sister of Sunan Bonang. From the marriage, Raden Fatihan or Ja'far Shadiq was born, known as Sunan Kudus.

In another explanation of the Sunan Kudus genealogy, (Nur Sa'id, 2010) mentions that the Sunan Kudus has the original name of Sayyid Ja'far Shodiq, often called Raden Hajji, 
who is known as Sunan Ngudung in Jipang Panolan. In this history, it is mentioned that Sayyid Ja'far Shodiq is the son of Raden Utsman Haji bin Raja Pandita bin Ibrahim alSamarqandi bin Maulana Muhammad Jumadi al-Kubra bin Zaen al-Husain bin Zain alKubra bin Ali Karamallah wajhah (husband of Fatimah bint Rasulullah S.A.W.).

Sunan Kudus respects the part of the religious structure of the Hindu-Buddhist community which still fills the space of life of the Kudus people at that time. As each person understand that cows are highly respected animals for Hindu-Buddhists. Based on the respect that is so high in the life of this Hindu-Buddhist society, Sunan Kudus once tied "nyancang" a cow around the yard of the Kudus Tower Mosque. In line with this fact, Van Dijk and P. Nas (1998) explained that Sunan Kudus forbade slaughter of livestock (cows) by his followers to avoid offending the Hindu community in the vicinity. This fact illustrates the strategic efforts of Sunan Kudus to spread Islam with compassion (rahmatan lil'alamin) for the Kudus people in general.

The emergence of such a good treatment of the animal that is respected by this HinduBuddhist society makes the followers of the ancient religion who are rooted in Kudus, moving to visit the Mosque of the Kudus Tower to answer the call of the Saint, Sunan Kudus. From this strategy, gradually the religion was conveyed (tabligh) so that the followers of Islam in Kudus were increasing without any significant resistance (Sholihin, 1986).

After Sunan Kudus passed away, community syncretism against Sunan Kudus is still running, even until now continues to grow as one of the religious tourism destinations which is utilized by surrounding community and Indonesian society in general. Etymologically, syncretism comes from the words syin and kretiozein or kerannynai, which means mixing conflicting elements. The word was introduced by Plutarch in the second century. In his essay, "de Fraterno Amore" the love of the brothers," Plutarch stated that although there was a quarrel between brothers, they would unite to face challenges from outside. The meaning is a movement in the field of philosophy and theology to present an attitude of compromise on things that are somewhat different and contradictory. Syncretism in religion is an attitude or view that does not question whether a religion is pure or not. Therefore, they tried to integrate good elements from various religions, which of course differed from one another, and made them as one sect and even religion (M. Darori Amin, 2000). According to AlQurtubi, "the process of syncretism becomes inevitable when there are encounters with two or more different cultures/traditions" (Sumanto, 2003).

Syncretism is an attempt to adjust the conflict of beliefs, while often in the practice of various schools of thought. This term can refer to the effort to join and make an analogy to some of the characteristics of tradition, especially in the theology and mythology of religion, and thus affirm a unified approach that underlies or allows being inclusive of other religions. Syncretism also occurs mostly in literature, music, art and other cultural expressions. 


\section{METHOD}

This study used qualitative methods and descriptive-qualitative analysis techniques that try to understand and interpret the meaning of an event in certain situations according to the researchers' context. Bogdan and Taylor stated that qualitative research, in turn, produced descriptive data in the form of words, both written and oral (Nyoman Kutha, 2010)

The most important feature of qualitative method lies in the meaning of messages, in the process, with no distance between subjects and research, open and scientific (Nyoman Kutya, 2009). While the historical approach to the object of research are very useful for tracing whether social and cultural changes occur in the context of the age and environment. In qualitative research, researchers themselves are key informants both in data collection and data analysis. Furthermore, there are several methods of data collection that are carried out through observation, in-depth interviews, and document studies. Data collection and data analysis are carried out simultaneously by exploring the forms, factors, and interpretations of meaning through syncretism theory.

\section{DISCUSSION}

\section{Prohibition of Slaughtering Cows}

In attracting Hindus, Sunan Kudus then tied the ox (cow) in the yard of the tower mosque with the intention to attract the attention of Hindus who worship the ox so they come to the mosque. After the Hindus came to the courtyard of the mosque, Sunan Kudus said welcome and then talked, preached, and exchanged dialogue. In order to win the hearts of Hindus, Sunan announced a ban on Kudus people not to slaughter and eat beef. The aim is to respect Hindus. With this method, finally, most Hindus became sympathetic to Sunan Kudus and were willing to convert to Islam. Such is the appeal of Sunan Kudus that makes his missionary activities successful.

This prohibition is a symbol of respect for Hindus who at that time were still a majority, whereas the cow is not forbidden for the followers of Islam. Until now, the people of Kudus still uphold the tradition of not slaughtering cows, including on the feast of the sacrifice/Eid al-Adha. Instead, the Kudus people prefer to slaughter buffalo or goats. According to folklore, another reason why the Kudus community never slaughtered a cow was that it followed what Sunan Kudus had done. In the past, Sunan Kudus had felt thirsty, and then was helped by a Hindu priest with cow's milk. As an expression of gratitude from Sunan Kudus, the Kudus people are forbidden to slaughter cows (Sri Indrahti, 2012).

\section{Dandangan}

Every time before Ramadan comes, Muslims in Kudus, Central Java and surrounding districts greet it with joy. The momentum of Ramadan's presence becomes something 
special because there is a tradition of Dandangan as a marker of Ramadan. This tradition has been passed down to the inheritance of Sayyid Ja'far Sodiq or often known as Sunan Kudus. Dandangan tradition has been going on for hundreds of years. In the past, this tradition began when people came to the mosque to listen to the announcement from mosque elders about when to start the first day of Ramadan. The announcement began with the beginning of beating the bedug (drum) that is installed in the tower, then the bedug (drum) sounds like "dhang ... dhang..dhang". The sound of the bedug (drum) is what gave rise to the word dhandhang, so the habit is known as the Dandangan tradition.

The culmination of the Dandangan Tradition was the day before the fasting month when the evening approached, Bedug at the Tower Mosque was beaten haphazardly and at night the local religious leaders have announced the start of the fasting month the next day. After this announcement, that night also held tarawih prayers at Tower Mosque.

If in the past the community attended the Tower Mosque at the end of the Sha'ban towards the beginning of Ramadan to look forward to the announcement of the beginning of fasting. Now, the Dandangan tradition morphed into a large and festive tradition. Including its festivity brings a blessing to the wider community. For three weeks before Ramadan, the streets around Tower mosque complex and Sunan Kudus mausoleum were flooded by traders selling all sorts of merchandise, from food, clothing, toys, accessories, to daily necessities (M. Syakur).

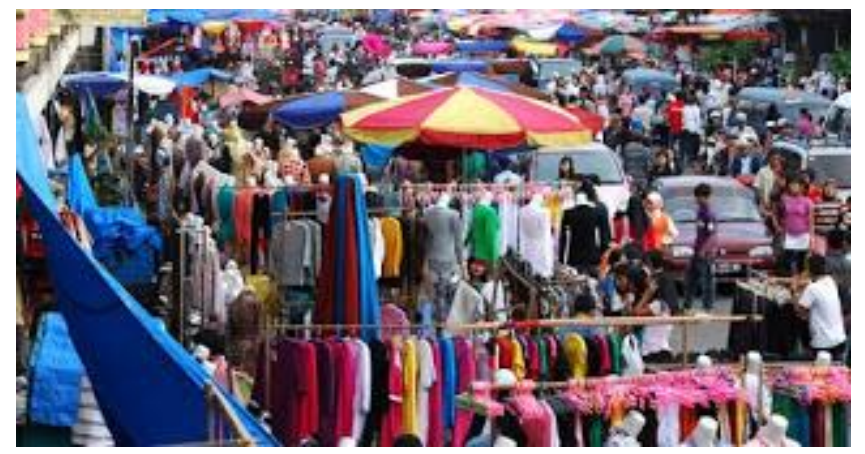

The atmosphere of the Dandangan tradition

\section{Gusjigang}

Sunan Kudus in his preaching taught his students to understand and apply the philosophy of (bagus, ngaji, and dagang [English: good, ngaji (studying/reciting Al-Quran), and trading). The definition and philosophy of Gusjigang are as follows:

\section{$\boldsymbol{G U S}=\boldsymbol{B} \boldsymbol{A} \boldsymbol{G} \boldsymbol{U} \boldsymbol{S}$ (Good)}

Kudus residents are people who have good attitude and behavior. The manifestation of Gus's teachings is physically a genuine dress style of Kudus society consisting of cap, collared shirt, wear Coat and wear Sarong. This style of dress is the typical style of the students in the boarding school, although in their daily life they do not always wear a suit. The Kudus Society honors one another with the call of Kang, which is the acronym 
KangJeng or Kanjeng which means Ingkang Jumeneng (who stands or who is respected). In everyday relationships with people of the same age, the Kudus people are egalitarian (the same), so the language used is Javanese ngoko. As a person of good attitude and behavior, the Kudus people are the one who can hold trust and trusted.

\section{$\boldsymbol{J I}=$ MENGAJI (Studying Al-Qur'an)}

Mengaji in this context is learning, not only Religion but also General Science as a provision in life. Kudus people, especially Kudus Kulon (West Kudus), when they are in the morning they will study in many public and religious schools in the West Kudus area. In the afternoon, they will add knowledge by studying the Holy Qur'an in Education Park. The Kudus Communities also regularly attend recitations held by the Board of Trustees of the Mosque, Tower, and Tomb of Sunan Kudus (YM3SK) on every Friday morning after the Morning Prayer and the Pitulasan recitation which is routinely held every Ramadan.

\section{$G A N G=D A G A N G$ (Trade)}

Trading is 9 out of 10 fortunes given by Allah SWT to His people. Sunan Kudus as the founder and role model of the Kudus community is a successful and wealthy merchant. No wonder then, most of the Kudus community is a resilient, wealthy and successful entrepreneur.

Sunan Kudus taught the Kudus people the philosophy of Gusjigang, as a spirit that must be maintained in order to improve the quality of themselves and the economy as a living provision. To be called a wong Kudus (Kudus people), one must have good physical behavior and appearance, good appearance, good attitude, and good behavior (GUS). This kind of behavior is then refined by always reciting (JI), reciting the Holy Qur'an here is intended to seek knowledge of both religious knowledge and knowledge as a provision of life and proven by trading experts (GANG) (Nur, Sa'id, 2013).

Gusjigang's philosophy taught by Sunan Kudus at that time still exists and imprints up to now in the daily life of the Kudus community. Gusjigang practice can be found in community activities around the Tower Mosque which in fact most of the merchants, who still spend every day to spend time in Kudus Tower Mosque and behave well and honestly in running their business.

\section{Sunan Kudus's Asyuro porridge}

At the time of the transfer ceremony at the grave of Sunan Kudus netting or called by tradition Bukak Luwur, when the ceremony takes place, provided Asyuro porridge and cicada rice that can be enjoyed by all visitors.

Women were busy preparing the Asyura porridge during the traditional bukak luwur ceremony at the tomb of Sunan Kudus. These women prepared hundreds of pepes of Asyura porridge which will be distributed to the surrounding community. This porridge was made when the Syura arrived. The month of Syura is another name for the month of Muharram, the first month of the Islamic calendar (Hijriyyah). Asyura Porridge was defended, 
supposedly because it was a sign of Noah when he survived the flash flood on the 10th of Muharram (in Arabic called Ashura or the tenth day).

\section{Ceremony at the grave of Sunan Kudus netting or called by tradition Bukak Luwur}

Usually, this Asyura porridge is made and distributed a day before the opening of the Bukak Luwur, that is on the 9th of Muharram. Asyura Porridge is made from 8 different ingredients. "There are rice, corn, soybeans, cassava, cowpea, bananas, green beans and peanuts," he explained. Eight of these ingredients are said to be in accordance with Noah Asyura's porridge which is also made of 8 food ingredients. Apart from these ingredients, in Asyura porridge is also sprinkled with several other snacks. Like, pentul, sprout, red chili, fried tofu, fried tempeh, fried anchovies, shrimp and so on.

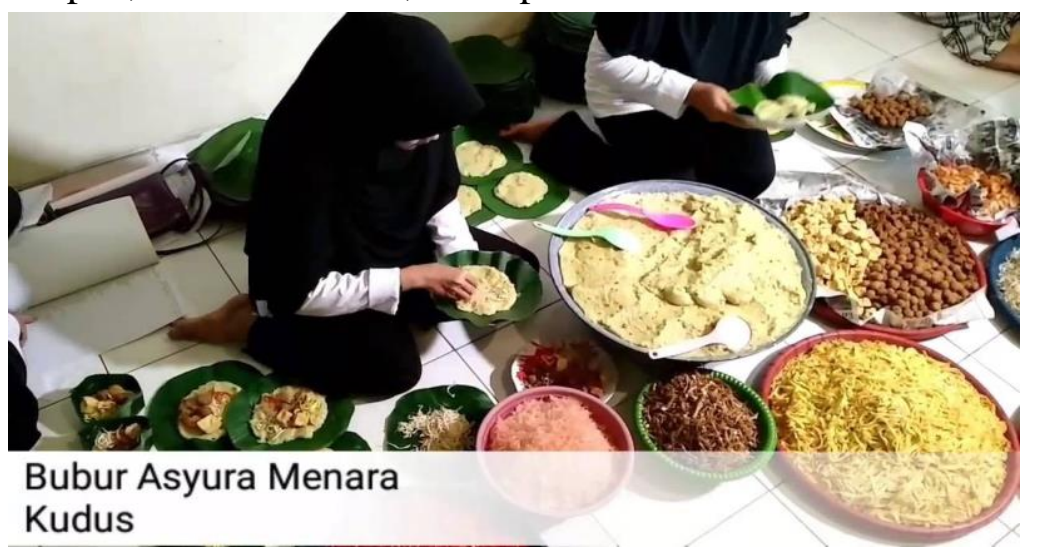

Pentul itself is a round fried food made from various ingredients. "From coconut, meat, wheat, mixed with brown sugar and added with orange leaves," he said. After all, ingredients are mixed, then rounded up small and then fried until cooked (Sri Indrahti, 2012).

Selametan (salvation) with Asyura porridge tradition even this up to this era are still performed by the Kudus citizens at the time of the transfer ceremony at the grave of Sunan Kudus netting or called by tradition Bukak Luwur.

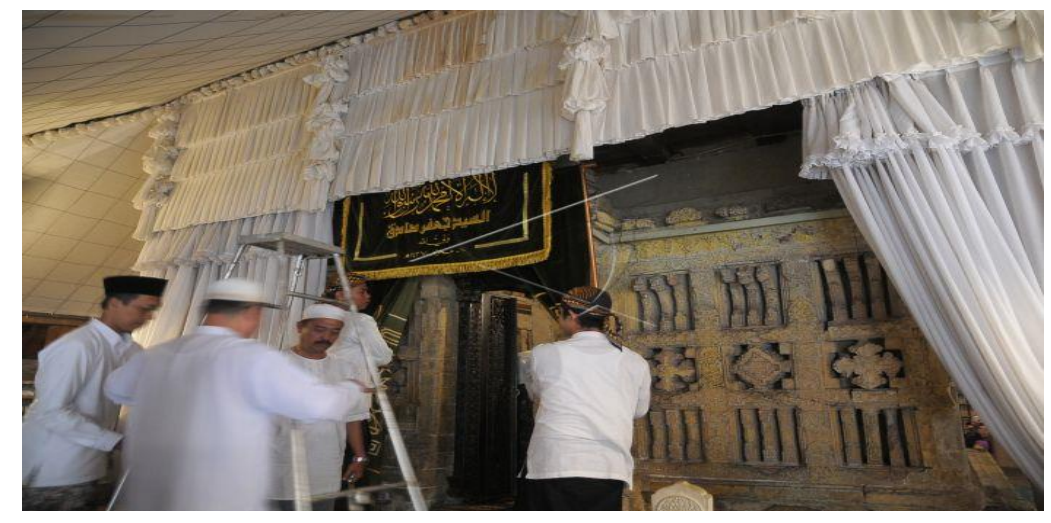

43| Journal of Economic Tropical Life Science , 4(2) 


\section{CONCLUSIONS}

In spreading da'wah Sunan Kudus uses the following cultural approach: Creating a Cultural Sphere, Acculturation, Treatment of Disease, Modeling, and Networking. Until now the Kudus community still believes not to slaughter cows. So the needs of everyday meat, as well as the day of sacrifice in Kudus people, always trust not to slaughter the cow and replaced with other animals.

The Dandangan tradition is still carried out today by the Kudus community and it is a religious tourism activity of the Kudus Regency, which is always crowded with tourists both from Kudus and from outside the Kudus city. The Kudus Community is still carrying out the philosophy of Sunan Kudus GUSJIGANG (good, reciting Al-Qur'an and trade). Always doing good for the world and the hereafter. Kudus, especially in the Sunan Kudus Tomb complex, stand many famous Islamic boarding schools which are used for reciting or developing religious knowledge. The Kudus Community in general and the people in the complex around the Tomb of Sunan Kudus have their livelihood as traders.

Selametan (salvation) tradition with Asyura porridge is still carried out today by the Kudus residents during the net replacement ceremony at the tomb of Sunan Kudus or called as Bukak Luwur tradition.

\section{REFERENCES}

Aldyan, R. A., Warto, W., \& Marimin, M. (2019). " Ngalab Berkah" on the Tradition to Open Luwur the Sunan Kudus Tomb. International Journal of Multicultural and Multireligious Understanding, 6(4), 156-165.

Aldyan, R. A. (2020). The Commodification of Religious Tourism in the Tomb of Sunan Kudus. Cultural Tourism Research, 2(7), 32-47.

Ashadi, A. (2017). Correlation Between the Mosque and Traditional House Architecture in Kudus, Indonesia. International Journal of Built Environment and Scientific Research, 1(01), 17-26.

Amin M. Darori. (2000). "Islam dan Kebudayaan Jawa”. Yogyakarta: Gama Media.

Al-Qurtubi, Sumanto. (2003). “Arus Cina Islam-Jawa Bongkar Sejarah Atas Peranan Tionghoa dalam Penyebaran Islam di Nusantara Abad XV \& XVI”. Yogyakarta: Inspeal Ahimsakarya Press.

Dewi, A. P. (2018). Sinkretisme Islam Dan Budaya Jawa Dalam Upacara Bersih Desa Di Purwosari Kabupaten Ponorogo. RELIGIA, 96-107.

Dewi, E. W., Nurkamto, J., \& Drajati, N. A. (2019). EXPLORING PEER-ASSESSMENT PRACTICE IN GRADUATE STUDENTS'ACADEMIC WRITING. LLT Journal: A Journal on Language and Language Teaching, 22(1), 58-65.

Ediyono, S. (2017). Islam and social integration in the reflection of the nusantara society. Afkaruna: Indonesian Interdisciplinary Journal of Islamic Studies, 13(2), 148-167.

Fahmi, R., \& Aswirna, P. (2019). ISLAM NUSANTARA: PREJUDICE AND SOCIAL CONFLICT. HUNAFA: Jurnal Studia Islamika, 16(2), 55-82.

44| Journal of Economic Tropical Life Science , 4(2) 
Farihah, I., \& Ismanto, I. (2019). Buka Luwur as A Media of Education and Social Solidarity of Kudus Community. Al-Tahrir: Jurnal Pemikiran Islam, 19(1), 141-159.

FOURNIE, P. (2019). ZIARAH (PILGRIMAGE) AND THE LEGACY OF COEXISTENCE IN INDONESIA. Peace Journeys: A New Direction in Religious Tourism and Pilgrimage Research, 152.

Garadian, E. A. (2019). Para Wali Nyentrik: Rekontekstualisasi Islamisasi di Tanah Jawa, Menantang Fundamentalisme Islam. Studia Islamika, 26(2).

Habibi, H. (2018). Protecting National Identity Based On The Value Of Nation Local Wisdom. International Journal of Malay-Nusantara Studies, 1(2), 24-40.

Habibi, H. (2016). PERAN KI DALANG BASARI (1950-2003) DALAM PERKEMBANGAN ISLAM DI GEGESIK CIREBON. Jurnal Tamaddun: Jurnal Sejarah dan Kebudayaan Islam, 1(2).

Indrahti Sri. (2012). "Kudus dan Islam: Nilai-Nilai Budaya Lokal dan Industri Wisata Ziarah". Semarang: CV Madina.

Jakl, J. (2019). History of a ritual meal in Java. Routledge Handbook of Food in Asia.

Kaprabowo, A. (2019). Beyond Studies Tarekat Rifa'iyah Kalisalak: Doktrin, Jalan Dakwah, dan Perlawanan Sosial. Jurnal Pemberdayaan Masyarakat: Media Pemikiran dan Dakwah Pembangunan, 3(2).

M.Syakur. "Tradisi Masyarakat Islam Di Kudus Jawa Tengah". The article of FAI Universitas Wahid Hasyim Semarang Lecturer.

Mubasyaroh, M. (2017). ACCULTURATION AS ADAKWAH MODEL OF SUNAN KALIJAGAIN PORTRAITOFISLAM NUSANTARA. TASÂMUH, 14(2), 127-144.

Muqoddam, F., \& Maghfiroh, V. S. (2019). Syncretism of Slametan Tradition As a Pillar of Islam Nusantara. KARSA: Journal of Social and Islamic Culture, 27(1), 75-93.

Nyoman Kutha Ratna. (2009). "Teori Sastra dari Strukturalisme Hingga Postrukturalisme Perspektif Wacana Naratif”. Yogyakarta: Pustaka Pelajar.

Salam Sholihin. (1986). “Ja'far Shadiq Sunan Kudus”. Kudus: Menara Kudus.

Saragih, D. B. (2019). Religions in Indonesia: a Historical Sketch. In Research in the Social Scientific Study of Religion, Volume 30 (pp. 54-66). Brill.

Sa'id Nur. (2010). “Jejak Perjuangan Sunan Kudus dalam Membangun Karakter Bangsa”. Bandung: Brillian Media Utama.

Sa'id Nur. (2013). "Filosofi Menara Kudus Pesan Damai Untuk Dunia”. Kudus: Brilian Media Utama.

Setiawan, A. R., \& Inayati, F. (2019). Islam Nusantara: Glance History, Characteristics, and Criticism.

Supatmo, S., \& Syafii, S. (2019). NILAI MULTUKULTURAL ORNAMEN TRADISIONAL MASJID-MASJID WARISAN PARA WALI DI PESISIR UTARA JAWA. Imajinasi: Jurnal Seni, 13(2), 1-14.

Susilo, S., \& Syato, I. (2016). Common identity framework of cultural knowledge and practices of Javanese Islam. Indonesian Journal of Islam and Muslim Societies, 6(2), 161-184.

Usamah, U. (2019). Transformasi Islam dari Demak hingga Mataram (Doctoral dissertation, UIN Sunan Ampel Surabaya).

45| Journal of Economic Tropical Life Science , 4(2) 